\title{
FCC REGULATION OF COMPETITION AMONG RADIO NETWORKS
}

I.

Tне Federal Communications Commission recently promulgated chain broadcasting regulations" with the purpose of combatting an alleged "monopolistic domination" of chain broadcasting by limiting network ownership of stations and by regulating contractual relations between network companies and their affiliated stations. Action against network "monopoly" has long been demanded by Congress, ${ }^{2}$ but the present regulations have evoked bitter criticism ${ }^{3}$ of the Commission from the major portion of the industry. ${ }^{4}$

The legal and economic patterns of the radio broadcasting industry have been determined by the physical art, ${ }^{5}$ and the most important physical limitation has been the scarcity of broadcast channels available for distribution among entrepreneurs. ${ }^{b}$ Though statutes providing for regulation of broaclcasting in the United States have been written in terms of regulating stations, the stations are only the base of the broadcasting industry. Its superstructure is the network companies which unite the individual stations into chains.

1. FCC Order of May 2, 1941, Docket No. 5060, as amended by FCC Order of October 11, 1941, hereafter referred to as the regulations. For the text of the regulations see note 32 infra.

2. See Hearings before Committee on Interstate Conmerce on the Nomination of Thad H. Brown on Reappointment as Federal Communications Commissioncr, 76t 1 Cong., 3d Sess. (1940) 236, and Hearings before Committee on Interstatc Commerce an S. Res. 113, 77th Cong., 1st Sess. (1941) 237, 256, 438 (hereafter cited as : Hearinys on S. Res. 113).

3. The controversy over the regulations was described by FCC Chairman Fly as a “slugging match." Hearings on S. Res. 113, p. 99.

4. The four national networks are owned by three companies; The National Broadcasting Company owns two, and the.Columbia Broadcasting System and Muttual Broadcasting System each own one. NBC and Columbia have opposed the regulations, and Mutual has been in favor of them.

5. See Shulman, Legal Aspects of Radio, 13 Evcyc. of Soc. Scr. (1930) 66.

6. The portion of the radio spectrum useful for standard broadcasting is the band between 550 and 1600 kilocycles. To afford interference-free transmission it has been divided into 106 channels of three types: clear channel, regional channel, and local channel. Clear channels are for high powered stations. Each regional channel is available for several medium power stations of different regions. Each local channel is used by numerous low powered stations. FCC, Radio, A Public Primer (1941) 4-5. The necessary scarcity of facilities available for Class I stations results in a numerical preponderance of small stations, but the effective area coverage of Class I stations causes them to have an earning power and a significance in public policy considerations highly disproportionate to their numbers. See FCC REport on Chain Brondcasting (1941) 32 (hereafter cited as: Chain Broadcasting Report). 
Chain broadcasting, or the "simultaneous broadcasting of an identical program by two or more connected stations," 7 offers obvious advantages which make its extensive use inevitable. To advertisers chain broadcasting offers the opportunity of reaching a national audience and, by increasing the numbers of listeners of a given program, reducing the program's production cust per listener. For listeners in all regions chain broadcasting malies available expensive programs produced only in a few talent centers, such as Yew York and Los Angeles. To station owners chain broadeasting offers revenue from the national market and programs satisfying the statutory obligation tu broadcast in the public interest.

The networks have three major functions: selling network time to national advertisers, producing programs (commercial and sustaining), and distriluting these programs to affiliates. $\$$ To carry out these functions the nctworlss maintain extensive sales forces, operate elaborate studios, lease thousands of miles of wire-lines, and employ numerous personnel. They also own stations facilitating network operations. ${ }^{8}$

A substantial portion of radio advertising is purely lueal, such as the programs sponsored by small town retailers, and thus outside the scope if network operations. Even in national advertising the networlss have competition from national spot programs ${ }^{10}$ and transcriptions.11 Yet, "the brosslcasting business handled by the three national network organizatiuns, ( $x$ : cluding the non-network business of the stations owned by them) constitutes almost half of the total business of all commercial broadcast stations in the United States,"12 and at the end of 1938 network affiliates used $97.9 \%$ of the total night-time broadcasting power of the United States. ${ }^{13}$

The control of network broadcasting suggested by these figures is not evenly distributed within the industry. The older network companies, National Broadcasting Company ${ }^{14}$ and Columbia Broadcasting System, are substan-

7. Comatunications Act of 1934, $\$ 3(\mathrm{p}), 48$ Stat. 1065, 47 U. s. C. \$153(p) (1934).

8. See Chain Bro.docasting Report 77.

9. The Mfutual Broadeasting System, which differs greatly in structure from NBC and CBS, owns no stations but is itself owned by stations. Sce infra go 451 . NBC in

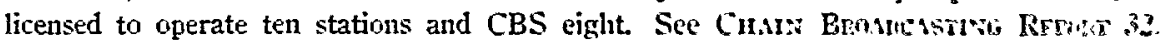

10. A national spot program is one in which a national advertiser sponsors the presentation on a local station of some interesting or imrortant local event, for cramils, a football game.

11. By using an electrically transcribed, or rccorded, prugram, a mational advcrtiser may distribute his progran to stations all over the country by mailing them the discs instead of using wire line conmections.

12. Chain Broadcasting Report 3.

13. See id. at 31 .

14. NBC is the oldest and most powerful chain broadeasting organization; it owns two of the four national networks. Though there are serarate sales forces and Irogram departments for the two networks, they have not been run as scrarate and distinct units. 
tially more powerful than the Mutual Broadeasting System. It is at the distribution of power among networks rather than the concentration of power in networks that the Commission has primarily directed the chin broadcasting regulations. The Commission seems to recognize that the preeminence of network broadcasting is in the public interest, ${ }^{15}$ but it takes the position that there should be competition between the networks, and that there should be five or six national networks instead of four. ${ }^{16}$ The Commission seeks to achieve these ends by regulating the contractual relationships between the networks and their affiliated stations.

The present standard contract ${ }^{17}$ between NBC and its affiliates provides that the network will guarantee the affiliate 200 unit hours ${ }^{18}$ of programs each contract month. Sustaining programs are supplied free of charge but the station receives no compensation for the first sixteen unit hours of network commercial programs broadcast through it during the contract month. For subsequent unit hours of commercial programs the outlet receives a sliding percentage of its card rate, according to a schedule which provicles for increasing station compensation as the volume of time sales increases.

These affiliation contracts cover a five year period, but NBC is given the power to terminate 'upon a year's notice. The station is forbidden to broarlcast the programs of other national networks, and though NBC is not expressly forbidden to send programs to other stations in the affiliate's territory it usually does not do so. Certain hours of the broadcast day are designtated as network optional time, and the outlet is obliged, upon 28 days notice, to take network commercial programs offered for these hours. The station may reject such a program only if its broadcast "would not be in the public interest, convenience and necessity." According to a report by the majority of the Commission made after a Committee investigation of network monopoly, these provisions for long term affiliation, exclusivity, and option time, and their counterparts in the affiliation contracts of the other networks are the heart of the monopoly problem, ${ }^{10}$ and it is at these provisions that the

The Red and Blue are separate networks only in that NBC has duplicate outlet facilities in many cities which are available for the simultaneous network broadcasting of different programs over substantially the same area. Studio facilities are used intetchangeably by both networks; volume discounts are based on the customer's use of both networks; and NBC does not allocate income and expenses between the Red and Bluc networks. NBC affiliation contracts do not specify with which network the station shall be affiliated, and many stations are used on both. See id. at 44-45.

15. See id. at 4,77 .

16. See testimony of FCC Chairman Fly in Hearings on S. Res. 113, p. 146.

17. For a copy of the standard NBC affiliation contract, see id. at 107-12.

18. The most desirable night-time broadcasting hours count as one unit hour, and less desirable broadcasting hours count as fractions thereof. Afternoon hours count as half a unit, and hours between midnight and $\delta$ a.m. count as one-third of at unit. Id. at 108.

19. See Chain Broadcasting Report 34 . 
first five chain broadcasting regulations ${ }^{20}$ were directed. One of the remaining regulations ${ }^{21}$ was aimed at the ownership of two networks by one company, and was thus applicable only to NBC.

Although the organization and contractual scheme of the Columbia Broadcasting System are fundamentally the same as those of $\mathrm{NBC}, 2$ the structure of the Mutual Broadcasting System differs radically from that of the other two. Mutual is "in form a corporation for profit, but actually a non-profit, cooperative enterprise." 23 Its stockholders all are broadcasting organizations. Mutual stations are either members, participating members, or affiliates. "The member stations underwrite all operating deficits and wireline clarges; and the participating members contribute in varying degrees toward the expenses of Mutual and their wire line connections to Mutual's main line." Affiliates pay the cost of the wire-line connection from their stations to the Mutual main line.24 MIutual itself owns no studios ${ }^{25}$ and, with the exception of certain news broadcasts, does not produce sustaining programs. The central organization selects sustaining programs of individual associattes and sends them out on the wire for the use of the network.

Since February, 1940, Mutual contracts have contained clauses prohilitiug stations licensed to its stockholders from taking programs of uther netwurls, and some of Mitual's contracts also bind the network not to feed programs to other stations in the service area of the associated station. ${ }^{26}$ The contracts with stockholders run for five year periods, but after two years stations may cancel by giving a year's notice. With affiliates owning no stuck Mutusl's contracts are generally only for one year.

Mutual is much smaller than $\mathrm{NBC}$ or CBS. Since its inceptiun in 1934 the number of its associated stations has increased to a present total of approximately $190,{ }^{27}$ but only two of these are clear channel stations, and about 100 are small local stations. In 1940 time sales of NBC (after discounts; before commissions) totalled $\$ 37,11 \$, 130$, those of CBS $\$ 31,1 \$ 1,444$, and those of Mutual $\$ 3,600,161.2 \mathrm{~s}$

20. Regulations, $\$ \$ 3.101-3.105$. See note 32 infra.

21. Section 3.107 , now indefinitely suspended. See nute 32 infra.

22. CBS contracts include rigorous exclusivity clauses grohibiting ustlets from taling the programs of other networks and also forbidding the networl: to give prograni, to other stations in the service area of its outlet. CBS's typical contratt, litis NEL"s, binds the station for five years at the option of the network, and also cuntains pruvisinn?

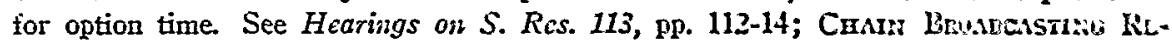
PORT 35-42.

23. See N. Y. Times, Nov. 1, 1941, p. 32, col. S; sce also Hearings on S. Res. 113. p. 156.

24. Chain Broadcasting Report 28.

25. But see N. Y. Times, Nov. 1, 1941, p. 32, cul. \&.

26. See Hearings on $S$. Res. 113, pp. S485, 164.

27. See N. Y. Times, Nov. 1, 1941, p. 32, col. S.

28. See Chain Brodncisting Report 41, 42, 28. 
Both Mutual and the Commission contend ${ }^{20}$ that the long term affiliation contracts made by NBC and CBS, coupled with exclusivity and option timc practices, deprive Mutual of an opportunity to rise to a position of equal strength, and that Mutual is especially handicapped by its inability to secure satisfactory outlets in many important cities where there are only two or three stations, all either owned by NBC or CBS, or under restrictive contracts with them.

NBC and CBS maintain that their predominance is due to early entrance into a speculative field, that the practices complained of are necessary for the conduct of stable and responsible network systems, and that the Commission is without jurisdiction to issue or enforce the chain broadcasting regulations. ${ }^{30}$

\section{II.}

The Communications Act of $1934^{31}$ does not expressly delegate to the Commission the power to regulate networks ; enforcement of the chain broadcasting regulations ${ }^{32}$ thus depends upon the Commission's control over in-

29. See Brief, and Supplemental Brief for Mutual Broadcasting System before the FCC in Matter of the Investigation of Chain or Network Broadcasting, Monnpaly in the Broadcasting Industry and Related Matters.

30. See Brief and Supplemental Brief for National Broadcasting Company before the FCC in Matter of the Investigation of Chain or Network Broadcastiny, Monopuly in the Broadcasting Industry and Related Mattcrs (hereafter cited as NBC Briws, anil NBC Supplemental Brief).

31. 48 Star. 1064-1105, 47 U. S. C. $\S \S 151-55,201-21,301-29,401-16,501-05$, 601-011 (1934) (hereafter cited as: Comnunications ACT of 1934).

32. The regulations, as amended, are:

3.101. No license shall be granted to a standard broadcast station having any contract, arrangement, or understanding, express or implied, with a network arganizaltion under which the station is prevented or hindered from, or penalized for, broadcasting the programs of any other network organization.

3.102. No license shall be granted to a standard broadcast station having any con. tract, arrangement, or understanding, express or implicd, with a network orgauization which prevents or hinders another station serving substantially the saune arca from broadcasting the network's programs not taken by the former station, or which prevent:s or hinders another station serving a substantially different area from broadcasting any program of the network organization. This regulation shall not be construed to prohibit any contract, arrangement, or understanding between a station and a network organiza tion pursuant to which the station is granted the first call in its primary service arca upon the programs of the network organization.

3.103. No license shall be granted to a standard broadcast station having ally contract, arrangement, or understanding express or implied, with a network organization which provides, by original term, provisions for renewal, or otherwise for the affiliation of the station with the network organization for a period longer than two years: Provided, That a contract, arrangement, or understanding for a period up to two years, may be entered into within 120 days prior to the commencement of such period.

3.104. No license shall be granted to a standard broadcast station which options for network programs any time subject to call on less than 56 days' notice, or more time 
dividual stations. The regulations merely state that no license shall be granted to stations having contracts with networks which engage in the specified disfavored practices.

The Commission contends that the regulations come within the grant of power in Section 303(i) to make special regulations applicable to stations engaged in chain broadcasting, or, alternatively and collaterally, are justifialile under Section $303(f)$ as regulations appropriate to carrying out the provisions of Section 307 (a) and (d) which govern the issuance and renewal of licenses in the public interest.

than a total of three hours within each of four segments of the brriadsast day, as herein described. The broadcast day is divided into 4 segments, as follows: 8 a. m. th 1 p. m.; 1 p. m. to 6 p. m.; 6 p. m. to 11 p. m.; 11 p. m. to 8 a. m. Such ortiuns may not lis exclusive as against other network organizations and may not frevent or hinler the slation from optioning or selling any or all of the time covercd by the rition, or other time, to other network organizations.

3.105. No license shall be granted to a standard breadeast station having any contract, arrangement, or understanding, express or implied, with a nctwork organization which (a), with respect to programs offered fursuant to an afiliation cuntrast, prevents or hinders the station from rejecting or refusing networl: programs which the station reasonably believes to be unsatisfactery or unsuitable; or which (b), with respect to network programs so offered or already contracted for, frevents the station from rejecting or refusing any program which, in its opinion, is contrary to the public interest, or from substituting a program of outstanding local or national importance.

3.106. No license shall be granted to a network organization, or to any fiarcon directly or indirectly controlled by or under common control vith a networl: organizztion, for more than one standard broadeast station where one of the stations corers substantially the service area of the other station, or for any standard hroadcast station in any locality where the existing standard broadcast stations are so few or of such unequal desirability (in terms of coverage, power, frequency, or other related matters) that con1petition would be substantially restrained by such licensing.

3.107. No license shall be issued to a standard broadeast station affiliatcd with a network organization which maintains more than one network: Provided, That this regulation shall not be applicable if such networls are not onerated simuitansausly, or if there is no substantial overlap in the territory served by the group of stations comprising each such network.

3.108. No license shall be granted to a standard broadeast station having any contract, arrangement, or understanding, express or implicd, with a nctworl: organization under which the station is prevented or hindered from, or fenalized for, fixing or altering its rates for the sale of broadcast time for wher than the netwarli's prowrams.

IT Is FURTHER OXDERED, That these regulations shall breome effective inmediately: Provided, That, with respect to existing contracts, arrangements or understandingr, if network organization station licenses, the effective date shall be deforrd until Nuvember 15, 1941; Provided further, That the effective date of Regulation 3.10; with respect to any station may be extended from time to time in order to permit the orderly dir = position of properties; and Pracided further. That the effective Jate of Regulation 3.107 shall be suspended indefinitely and any further order of the Commicsion I lasing caitl Regulation 3.107 in effect shall provide for not less than six months' notice and for further extension to the effective date from time to time in orfer to yermit the irflerly disposition of properties. 
Though Section 303(i) is written in broad terms, a persuasive argument can be made that the power granted is limited to technical regulations. ${ }^{33}$ This provision first appeared in a part of the Radio Law of $1927^{34}$ devoted to technical matters, and at the time of its enactment Congress probably believed it desirable to have special technical regulations for chain stations. ${ }^{96}$ There were current misapprehensions as to the possibility of synchronizing stations. Technicians generally thought that stations of a network might all operate on a common frequency without interference. Suggestions were made that, to prevent duplication of programs within a receiving area, it might be desirable to limit the power output of stations while broadcasting chain programs. If the drafters of the Act intended to give the Conmission power to make regulations broader in scope than the technical regulation of chain program broadcasting it would probably have been more convenient to give the Commission power over the network organization as such, rather than to confine the authority to regulating stations engaged in chain broadcasting.

Even without recourse to Section 303(i), however, the Commission may be empowered to issue the regulations by Section 307 (a) and (d) and Section 303(f). The standard of public interest, convenience and necessity governing the Commission's action on license applications is to be interpreted, said the Supreme Court, "by its context, by the nature of radio transmission and reception, by the scope, character, and quality of services."

This context test was applied by the Supreme Court in FCC v: Sandcrs Brothers Radio Station, ${ }^{37}$ in which a station owner sought to enjoin the granting of a new license which he claimed would create such competition that his station could not continue to operate profitably. The Court said: "An important element of public interest and convenience affecting the issue of a license is the ability of the licensee to render the best practicable service to the community reached by his broadcasts. That such ability may be assured the Act contemplates inquiry by the Commission, inter alia, into an applicant's financial qualifications to operate the proposed station." Though the remarks of the Court in the Sanders case referred to a refusal to isste a license permitting destructive competition, they would seem to apply as well to the converse situation, where the applicant for a broadcast channel will use the channel in such a way as to diminish competition to the detriment of program service. In both cases the controlling consideration is the effect

33. But see 68 Cong. Rec. 2881 (1926) ; 81 Cong. Rec. 2336 (1937).

34. 44 Stat. 1162 (1927) (hereafter referred to as: RAdio ACT of 1927).

35. See Hearings before Committee on Interstate Commerce an S. 1 and S. 1754, 69th Cong., 1st Sess. (1926) 212 et seq. See also testimony of Senator White in Hearings on S. Res. 113, p. 146.

36. Fed. Radio Comm. v. Nelson Bros. Bond \& Mtge. Co., 289 U. S. 266,285 (1933).

37. 309 U. S. 470,475 (1940). 
upon the broadcast service rendered to listeners, rather than merely upon the competitors..$^{3 s}$

The Commission's power to consider competition is fortified by the presence of a strong anti-monopoly policy in Title III of the Communications Act. The provision ${ }^{39}$ that no person shall own any property right in rollin channels, reinforced by the requirement ${ }^{20}$ that waiver of any claim to the use of a radio frequency shall be a precondition to the issuance of a license. and the provision ${ }^{41}$ limiting the term of license for broadcasting to three years, were designed to prevent the domination of the air by ownership ur vested interest groups.2 Furthermore, Section 313 expressly males the anti-trust laws applicable to "the manufacture and sale of and to trarle in radio apparatus and devices entering into or affecting" interstate or foreign commerce or radio communications; and a court, upon finding a licensee guilty of a violation of the anti-trust laws, is authorized to revole its licenses as an additional penalty. ${ }^{43}$

It may be contended that inasmuch as the issue of radio monopoly is determinable in the courts the Commission is without jurisdiction to make its own findings upon the question a basis for the denial of license applieations. But refusal of a license by the Commission under the chain broal- a casting regulations is not predicated upon violation of the anti-trust laws, but rather upon the theory that granting the application would limit competition and thus adversely affect program service. ${ }^{44}$

If the Commission may consider competition in issuing licenses, may it also promulgate prior regulations defining the practices which it will consider against the public interest and, therefore, grounds for refusing renewal

38. Other non-technical matters affecting the quality of program esrvice which have been held to justify the Commission's denial of a license applicatiun are: wunership of the proposed station by another station, Great Western Lroadeasting Ass'n, Ins. v. FCC, 94 F. (2d) 244 (App. D. C. 1937); the proposed station's lack of financial ability, Goss v. Federal Radio Comm., 67 F. (2d) 507 (Apr. D. C. 1931); and yrevious broadcast of objectionable matter by the applicant for a license renewal, Trinity Mcthodist Church South v. Federal Radio Comm., 62 F. (2d) 850 (Anp. D. C. 1932); KFIF Broadcasting Ass'n v. Federal Radio Comm., 47 Fed. (2d) 670 (Arr. D. C. 1931 ).

39. Connitunications Act of 193\%. $\$ \$ 301,300$ (h)(1).

40. See id. $\$ 304$.

41. See id. $\$ 307$ (d).

42. See FCC v. Pottsville Broadcasting Co., 309 U. S. 134, 137 (1940).

43. Section 311 directs the Commission to refuse any apritication for a license mats by persons having had previous licenses revoked by a court finding them guilty of such radio monopoly. Section 311 also authorizes the Commission to revolse the licence of a person so found guilty, even though the court does nut impise this alditi.nal penalty.

44. Conversely, the statutory mandate that the Commission shall refuse anplications of convicted monopolists having had licenses revoled hy a cutrt is not dependent upon an evaluation of the broadcast service rendered ly the applicant, or of the effect of granting the license upon the public interest. Section 311 applies to all licinsces found guilty of restraint of trade in radio apparatus and devices, whether or mut they have ever engaged in monopolistic broadcasting practices. 
applications? The standards of public convenience, interest and necessity defining the scope of the power to act upon license applications, are the same criteria, under the statute, which apply to the issuance of regulations, ${ }^{4 t}$ Furthermore, the regulation-making power should be employed to carry out the other provisions of the act and, therefore, may be presumed to extend as far as the Commission's other powers.

Moreover, the validity of the Commission's chain broadcasting regulations need not depend upon the rule-making power conferred in Section 303(i), but may rest upon Section 307 alone. It is clear that the so-called chain broadcasting regulations are not regulations within the sense of Section 502, in that they are not enforceable commands or prohibitions, violation of which is judicially punishable. They are, rather, an announcement of the policy the Commission intends to follow in the exercise of its discretion upon future license applications. ${ }^{48}$ Such declarations of policy are approved administrative practice. ${ }^{47}$ They disclose the grounds of Commission decisions, aid consistency of Commission action, and furnish a basis for prediction and compliance. The courts have recommended such declarations of policy to the Commission. ${ }^{48}$ It seems clear, therefore, that the regulations are within

- the Commission's power and that they will be sustained unless found by the courts to be unreasonable and arbitrary.

\section{III.}

Of the eight chain broadcasting regulations, one is designed to give licensees increased control over program matter, one to encourage competition between stations and their affiliated networks, and one to make available to other stations in each area network programs which have been rejected by the network's regular affiliate. Two of the regulations are designed to combat dominance of individual network companies by limiting network ownership and control of stations, and by limiting to one the number of networks which may be owned by a single company. And three are designed to increase competition between networks by limiting the term of affiliation contracts, forbidding stations to promise that they will take programs from one network only, and forbidding exclusive option time. The two provisions which seek directly to equalize the power of networks and make possible increased inter-network competition, are closely related to the affiliation term, station exclusivity, and option time regulations. These five regulations are

45. Comarunications Act of 1934, $\$ \$ 303,307$ (a).

46. The Commission so regards them; see Chain Brosdcasting Rruort 85. But see Complaint in NBC v. United States, Civil Action No. 16-178, paragraph 27, District Court for the Southern District of New York (1941).

47. See Sex. Doc. No. 8, 77th Cong., 1st Sess. (1941) 27.

48. Pottsville Broadcasting Co. v. FCC, 98 F. (2d) 288, 290-91 (App. D. C. 1938); Heitmeyer v. FCC, 95 F. (2d) 91,98 (App. D. C. 1937). 
the most important, but whether they will cause any substantial change in the pattern of the broadcasting industry is an open question.

Section 3.107, which seeks to terminate ownership of two networks by one company, has been indefinitely suspended, because a forced sale would occasion undesirable loss. The Commission believes, however, that "separate ownership . . . is so generally recognized to be desirable that . . a separation will soon occur without the spur of a legal mandate." 20 It is good Commission strategy to avoid a court test of the reasonableness of this section, since separate ownership of the two networks will probably be attained without it if the other regulations are upheld. Section 3.106 will force NBC to sell its interest in at least four stations which are located in cities where it owns or controls two stations, and it will probably choose to sell the Blue Network stations in those cities rather than the Red. ${ }^{00}$ In all likelihood the Blue stations will be sold in a group, as part of a whole network sale, in order to maintain the sale value of both stations and network. ${ }^{51}$

The theory of Section 3.106 is that network ownership of a station, especially in a region where outlets are scarce, gives the owning network an unfair advantage in competing for advertising with other networks not having access to satisfactory outlets. ${ }^{62}$ The regulation is also based upon the belief that concentrated control ${ }^{53}$ of radio is undesirable, and on the fear that the networks may sacrifice the interest of their affiliated stations for the stations which they own.

The five year term of affiliation contracts, sought to be shortened by Section 3.103, limited competition between networks for stations, and also served to make the rise of new networks exceedingly difficult.

49. FCC Suppleatental Report on Chain Brontensting (manifold cony) 14.

50. The greatest part of NBC's profitable advertising business has been done by the Red Network, and if only one network must be sold there is little doubt but that NBC will choose to sell the Blue. Disposal of networl-controlled stations would weal:en the network, and if stations must be sold in these four cities the less profitable Blue Network would be sacrificed. Sale of Blue Network affiliates in these four cities would also be preferable because the Blue stations are less desirable than the Red. NBC's Red station in Chicago, WMAQ, is authorized to broadeast full time, while the Blue station, WENR, has only part time authorization. In San Franciseo the Red station, KPO, has a strength of $50 \mathrm{KW}$, and the Blue Station only $792 \mathrm{KW}$. In Washington, D. C., the Red Station, WRC, is owned by NBC, and the Blue Station, WALAL, is operated under lease by NBC.

51. Even the dissenting commissioners agreed that one network ought to be sold. See dissenting opinion of Commissioners Case and Craven, FCC Supplesse:ital Reront on Chatn Broadcasting (manifold copy) 2.

52. See Chain Broadcasting Report 68.

53. Though network owned or operated stations are comparatively few in number, they include a large proportion of the important Class I stations. Hearings on $S$. Res. 113 , p. 19.

54. See Chain Broadcasting Repost 67-68.

55. See id. at 59-63. 
termination points of the affiliation contracts of the various stations were staggered over a five year period, any new network would have to choose its outlets from the less desirable residue of unaffiliated stations, or begin operations with one or two stations while waiting for the termination of contracts to afford opportunity for piecemeal increase in station affiliations. The long term contract emphasized the restrictiveness of the exclusivity clauses, now sought to be eliminated by Section 3.101, and the option time provisions, now limited by Section 3.104; and in every case they minimized network competition from national spot programs. For optimum sales results, the programs of an advertising series must be given on the same station, at the same day and hour every week for several successive months. Thus, the normal time for which advertisers contract is thirteen weeks. But optioned time must be given up to the network upon 28 days notice, and local, national spot, and non-option-holding networks, which broadcast a program on time subject to option, could be sure of only four successive weeks before being required to change their hour. Option time, however, is not merely a device to restrict competition, but is also a convenient solution of an otherwise complicated network traffic problem. The sale of network time requires simultaneous availability of all the stations of the desired network groups, and when a network has a program for a chain of 50 or 75 stations, each of which sells time for local and for national spot programs, it is often difficult to find an hour in which every station is open. As the advertising value of one hour differs from that of another, ${ }^{56}$ the traffic difficulty also hampers network sales efforts, since definite time offers cannot be made to the prospective customer. The exclusive option-time practice solved this problem by compelling every affiliate to take network commercial programs upon 28 days notice. All local programs, national spot programs, and programs of other networks, where there was no exclusivity provision, had to be scheduled subject to clearance for the affiliated network. This limited the option-holding network's traffic problem to clearing against its own programs and scheduling programs 28 days in advance.

The original regulations prohibited option time completely, but they have since been modified. ${ }^{67}$ As now written, Section 3.104 is a compromise between the convenience of option time as a device to protect the availability of whole networks against the intrusion of local programs and the unclesirability of option time as a device to block inter-network competition. The day is divided into four segments, the three most important having five hours

56. The evening hours between 8 and 11 are considered the most valuable, and Sunday afternoons are more valuable than other afternoons. See Joint Comurte on Radio Research, Study of Rural Radio OwNership and Use in the United States (1939) 20-22, and National Assoctation of Brondcasters, Urban Radio Listening in the United States (1941) 8-27.

57. See note 32 supra. 
each. In each segment three specified hours may be placed under so-called "non-exclusive network option," exercisable at no less than $\mathbf{5 6}$ days notice. A "non-exclusive option" may be given to one or more networks, but may not prohibit the station from selling or optioning the same time to other networks. Thus, the option-holding network or networks now get clearance of the optioned hours against local or national spot programs, but not against other networks. Local and national spot programs are assured of at least two hours in each segment from which they may no longer be ousted by networks. Even if they select an hour subject to option, under the lengthened notice requirement they have it for at least eight weeks of continuous broadcasting before they may be required to change.

The Commission minority, NBC, and CBS believe that the abolition of these contractual bonds will make it impossible for stable networks to exist, and that the regulations will create excessive commercialism and opportunism in network broadcasting. ${ }^{58}$ They argue that at present networks spend large sums for sustaining programs which they furnish to their outlets; but when stations are not exclusively affiliated with one network the sustaining service will benefit the other networks which use the station as much as the supplying network. Furthermore, an opportunistic network, by lowering sustaining expenses, can offer advertisers and stations better terms than can networks under the present mode of operation. They could obtain another competitive advantage at the public's expense by eliminating certain rural affiliates which advertisers do not desire to use, but which they use at present because networks offer stations in groups which must be taken as a whole.53 Thus, competition between networks might deprive commercially unprofitable rural areas of national network service. Hence, the argument runs, the regulations will cause the network business to degenerate into an irresponsible time brokerage, and advertising companies will dispense with networks entirely and arrange their own inter-station hook-ups. ${ }^{\text {co }}$ Control of broadcasting will be transferred from stable companies with a long-run interest in the industry to numerous out-of-the-hat operators.

The Commission majority, on the other hand, believes the regulations will cause no such radical reformation of the industry. They point out that it will not be practical for advertising companies to set up their own hook-ups, because they will probably not be able to gain access to key stations owned by the networks, and because they do not have leased wire line facilities to affect the hook-up. ${ }^{61}$

58. See Chain Broadcasting Report 115-39; dissenting opinion of Commissioners Case and Craven, op. cit. supra note 51. See also testimony of Niles Trammell and W. S. Paley in Hearings on S. Res. 113.

59. See Hearings on S. Res. 113, p. 165.

60. See NBC Brief, Point III; Hcarings on S. Res. 113, pp. 50S-13.

61. See id. at $62,63,85$. 
At present national advertisers pay the networks the card rates of the stations used, without added fee for wireline relays. The networks lease lines from the telephone companies at a cost of about $\$ 8$ per month per airline mile. The geographical pattern of the network, together with the large number of network stations, tends to minimize the ratio of line mileage to stations connected. While the telephone companies also have a price schedule for hourly connections, the hourly charge is 20 cents per airline mile, at which rate two and one-half 16 hour broadcasting days would cost as much as leasing a line for a whole month. ${ }^{62}$ The telephone companies also require considerable advance notice for deviational hookups and often cannot arrange them for lack of facilities. Even assuming hookups could be secured for a one hour network, the advertiser would be limited in his choice of time to the unoptioned portion of each segment, unless he wished to risk being ousted by network option. Finding an hour in the unoptioned portion of the segment which none of the desired stations has already sold will be very difficult, because of concentration there of local advertising purchases.

IV.

Though any prediction is conjectural, it is not likely that the regulations promulgated by the Commission will radically change the pattern of the radio industry. The two hours of unoptioned time in each segment will aid local and national spot advertisers and may cause an increase in the use of transcriptions for simultaneous multiple point broadcasting. But networks are not forbidden to contract for non-optioned time, ${ }^{03}$ and non-network users will still have to compete against them, even in the option-free portion of each segment.

In metropolitan areas adequately served by four or more stations, it seems likely that even without contractual shackles each station will tend to affiliate with one network from which it will take all its network programs. ${ }^{64}$ Custom, inertia, and business convenience indicate this result. The greatest change will probably occur in about twenty metropolitan areas which have three or fewer adequate outlets for the four networks. In the past Mutual has been unable to secure outlets in many of these regions and has, therefore, been unable to compete for certain national programs whose sponsors in-

62. The telephone companies offer several different qualities of transmission service. The prices here quoted are for Schedule's $A$ and $B$, which are the same grade of service. Schedule $A$ is for the monthly contract period with continuous use 16 hours a day, and Schedule B is for occasional use on an hourly contract period. Service on Schedules $A$ and $B$ permits transmission of 100-5000 frequencies, and is the grade of service usually used by networks. See FCC Accounting, Statistical and Tariff Dep't, Program Transmission Channel Rates (effective July 10, 1941).

63. Section 3.103. See Supplemental Report on Chain Brosdcasting (manifold copy) 8-9.

64. See testimony of L. G. Caldwell, Hearings on S. Res. 113, p. 160. 
sisted on covering them. ${ }^{65}$ Under the regulations MIutual cannot be barred by exclusive affiliation clauses, and it will not have to contract for time subject to the option power of rival networks. ${ }^{60}$

Station promiscuity in two-outlet and three-outlet regions may dictate a change in the system of indirect charge for sustaining service now employed by NBC and CBS. As Mrutual grows, it too will probably have to furnish sustaining programs. Competition among networks to place commercial programs on the stations of two-outlet and three-outlet regions may cause those stations to broadcast a disproportionately small number of "public service" sustaining programs, but the likelihood of decreased program quality this suggests will be mitigated by the increased albility of these stations to choose among commercial programs.

As previously suggested, ${ }^{67}$ the regulations will also probably induce NBC to sell its Blue Network, leaving four separately owned networls. Elimination of exclusive affiliation and exclusive option time might eventually result in the establishment of a fifth network, ${ }^{68}$ though this possibility is minimized by the limited number of available outlets. Increase in the number of national network companies is the most significant change that the regulations will bring about.

Whether five network companies will give better service than three is a question the answer to which involves the interrelation of many variables, including the following: the number of stations suitable for major network affiliationship; the amount of advertising revenue available for networks; the effect of the increase in the number of networks upon vire-line cost; and the effect of the increase upon the diversity of programs available to listeners at any given time. Some of these considerations are similar to those governing the determination of the optimum allocation of resources for public utilities. But the Commission has not attempted to justify the regulations by such a factual analysis. It advances in favor of the regulations only the general arguments that competition is desirable, and that the regulations will also protect free speech.

The Commission argues that by increasing station control over program content and by increasing the number of network companies the regulations will protect freedom of the air and insure fair presentation of controversial public issues. ${ }^{69}$ This argument seems to be based upon the generalization

65. See p. 452 supra.

66. See NBC Supplearental Bries 52: "The real controversy in this proceeding is between National, on behalf of its Blue Network and MIutual."

67. See p. 457 supra.

68. See Hearings on S. Res. 113, p. 146.

69. See testimony of Chairman Fly in Hearings on S. Res. 113, p. 151: "But the possibility of increased competition is only one of the results of our regulations. Even more significant is their impact upon the power to decide what goes out over the air. $\mathrm{By}$ requiring a divestiture of the red network from the blue, our regulations eliminate 
that decentralized control safeguards freedom. But the networks have shown no alarming disposition to dictate policy through their control of radio channels. Indeed, they are very conscious of their vulnerable position as an industry affected with the public interest. Business acumen has led them to adopt a policy of antiseptic news presentation ${ }^{70}$ and to remain irreproachably aloof from partisanship in public issues. Though there have been complaints that access to the air cannot be had by minorities, these complaints are mostly directed against individual stations and not against the networks. $^{\text {71 }}$

Even if it were true that decentralized control better protects free speech, the present regulations promise no great safeguard. There is little probability that the social and economic prejudices of four or five network companies will be significantly different from those of three network companies. And it is unlikely that the power given to stations to reject network programs will often be used in the interest of free speech or impartial presentation of public issues.

The other policy behind the Commission's desire for four networks is the encouragement of competition. The Commission, however, asserts no desire to open the network business to free competition in the full sense of the term, although NBC and CBS predict the regulations will have that effect. A prerequisite for such free competition would be the abolition of the present practice of leasing broadcast transmission wire line facilities, and the installation of additional facilities which could hook up any desired group of stations and could keep changing the grouping at the end of every half hour broadcasting period. Through its common carrier control over the telephone companies the Commission might be able to secure the installation of facilities to permit such kaleidoscopic shifts in hookup patterns, and probably could require the networks to charge for hookups at a specified

the control of N.B.C. over two Nation-wide networks, an unhealthy concentration in one single management group over access to listeners of the country. By decentralizing the power to decide what the public may or may not hear and by returning that power to the hundreds of station licensees all over the country, our regulations insure that the channels of information so vital to the preservation of democracy will remain open and unrestricted."

70. See, for example, CBS's memorandum on European war coverage, reprinted in Hearings on S. Res. 113 , p. 362 et seq.

71. See Kassner and Zacharoff, Radio is Censored (1936). "N.B.C. with its program series 'The Town Meeting of the Air' has made a notable contribution to public and uncensored discussion. Columbia presented a series of discussions on the subject of control of radio with such speakers as Anning Prall, William Green and Norman Thomas. Minority points of view are receiving more attention from the program departments of the networks and hence cries of censorship grow less frequent. However, most of the smaller stations and the larger independents remain shockingly narrow in their program approach." Id. at 7.- See also Frost, Is American Radio Demockatic? (1937) $74-84$. 
hourly rate applicable to all users. ${ }^{72}$ Under those conditions the removal of contractual barriers might permit free competition.

The most striking result of such free competition would be the separation of the three network functions. ${ }^{73}$ Already the telephone companies perform the actual task of transmitting programs from the point of origin to the broadcasting stations, and with transmission facilities equally available to everybody there would no longer be an advantage in common performance of the functions of selling time and supplying sustaining programs. Under those conditions there would be free competitive opportunity to sell station time on a commission basis and to produce suitable sustaining programs for sale to stations. Such a freely competitive organization ${ }^{\text {th }}$ of the industry would be radically different from that obtaining at present, and there would be no place in it for the present type of network company.

The Commission, however, has indicated no interest in establishing free competition through changing the transmission facilities practices; indeed, it has expressly accepted the postulate that networks of the present type ought to remain an integral part of the broadcasting system. ${ }^{75}$ In acknowledging this, the Commission is subscribing to limited competition, and thus cannot consistently justify the regulations merely with reference to the general desirability of competition. ${ }^{78}$

Competition between networks as a force to regulate program quality seems singularly inapplicable to the peculiar structure of American brozdcasting. Networks compete with each other for advertisers, stations and listeners. ${ }^{77}$ Competition for listeners seems relatively unimportant because

72. Conmunications Act of 1934, $\$ \$ 202$ (b), 215(b), 204, 205(a); Hcarings on S. Res. 113, p. 134.

73. See p. 449 supra.

74. For the disadvantages of such a system see p. 459 supra.

75. See Chatn Broadcasting Report 8S.

76. See id. at $47-49,56$. Besides arguing in general terms that competition will improve broadcasting service, the Commission seems to argue that, regardless of the effect on broadcasting service, the maintenance of competition is a duty of the Commission. "In the absence of Congressional action exempting the industry from the antitrust laws, we are not at liberty to condone practices which tend to monopoly ..." Id. at 46. But this inclusion of competition within the purview of the standard of public convenience, interest, and necessity would seem to be stretching the standard's meaning. See p. 455 supra. Certain provisions of the regulations, however, are directed against specific forms of restrictive waste. Station exclusivity, prohibited by Scetion 3.101, occasionally prevented stations from broadcasting outstanding programs of networks other than its affiliated network. A frequently cited example was the inability of NBC and CBS affiliates to broadcast certain World Series baseball games. See Hearings on $S$. Res. 113, pp. 173-75, 393-95. Section 3.102 will occasionally prevent listeners of a given region from losing a desirable network sustaining program. Under Seetion 3.102, when the network's regular affiliate has obtained a commercial program for that hour, the network will be able to give the program to another station in the service area.

77. Probably the most important competition for listeners is that between advertisers, or, more specifically, between the advertising companies which produce programs 
program preferences will exert much more influence than station or network preferences in attracting listeners during any half hour..$^{78}$ The number of listeners an advertiser can reach is, therefore, limited by the effective service area of the network he employs, but the number of listeners within a given service area is determined by the attractiveness of the program which he himself produces. Hence, network popularity will not be an important factor when advertisers choose between networks, and the increased competition between networks will make itself felt primarily in price competition. The economic desideratum of competitive price, however, is not relevant here. ${ }^{79}$ The cost of radio programs is not a matter of public concern, except insofar as it affects the quality of program service available to listeners, and is not the problem toward which the Commission has directed the regulations. Insofar as "monopolistic" networks are in a better position than competing networks to limit the time consumed by advertising announcements and to regulate the nature of advertising announcements, network "monopolies" would seem to be desirable. Despite its unique property patterns, the broadcasting industry is a public utility ${ }^{80}$ which, if it is to remain privately owned and operated for profit, will serve the public best when regulated in accordance with positive policy. Probably this affirmative policy should be at least outlined by a new Congressional statute, ${ }^{81}$ having as some of the aims of its positive regulatory policy ${ }^{82}$ (a) securing network service for commercially unprofitable regions, (b) raising the level of listener taste rather than catering to "average" taste, (c) scheduling the programs of different networks so that they supplement, rather than duplicate, each other, (d) minimizing advertising and raising its ethical and aesthetic quality.

It seems likely that these objectives can be attained most effectively through Commission control over networks. But they require regulations specifically directed to particular goals, rather than general faith in the power of com-

for the large advertisers. Each advertiser is, of course, vitally interested in attracting as large an audience as possible, and, irrespective of competition between networks, this interest insures competitive effort to make commercial programs satisfy popular taste.

78. A listener's choice of programs at any particular time is dependent upon several interrelated factors. The clearness with which his set receives different stations is very important. Between several stations that give good reception it is likely that the listener will choose the one that at the moment is broadcasting the program most suited to his tastes. Many listeners have a preference for network stations, and some for local stations. But choice of stations on the basis of affiliation with a particular network is probably negligible. See FCC Report on Social and Economic DATA (1937) 75-82, 103-04; Rose, National Policy for Radio Broadcasting (1940) 132-33.

79. The listener does not directly bear the cost of producing radio programs.

80. See Rose, Nattonal Policy for Radio Broadcasting (1940) 11-14.

81. Two bills have been recently introduced to amend the Communications Act of 1934 in regard to its radio provisions: S. 1806, 77th Cong., 1st Sess. (1941), and H. R. 5497, 77th Cong., 1st Sess. (1941). Neither provides for additional regulatory power.

82. See Rose, National Policy for Radio Broadcasting (1940) 273 ct seq. 